\title{
Experimentation the Influence of Problem-Based Learning Model on Critical Thinking Ability and Understanding the Mathematical Concept of Class VII MTs
}

\author{
Rois Mahfud Setiawan, Senja Putri Merona \\ Mathematics Education, Faculty of Teacher Training and Education \\ University of Muhammadiyah Ponorogo \\ mahfudrois5@gmail.com,
}

\begin{abstract}
This study aimed to determine whether the problem based learning models was better than conventional learning models in terms of critical thinking and mathematics conceptual understanding. Based on observations at MTs-N Sampung Ponorogo, it was obtained that students' mathematics conceptual understanding and critical thinking were quite low. This research was a quasi-experimental with the population students of class VII MTs-N Sampung Ponorogo. The sample was class VII A given a conventional learning model and class VII B given a problem-based learning model. Reasearch data was collected by using test. Pretest and postest was used to get preliminary and final data. Pretest data was analyzed by using t-test while posttest data was analyzed by using the Mann Withney U test. The results of this study were the students' ability on critical thinking and matematical conceptual understanding used problem based learning models was better than students' used conventional learning models
\end{abstract}

Keywords: Cooperative Learning, TGT, Creativity, Comprehension of concepts

\section{INTRODUCTION}

Mathematics is one branch of science that deals with ideas and concepts of extract. In addition, the material in mathematics is hierarchically arranged (Hudoyo in Hasratuddin, 2014: 30). The concepts contained in mathematics are related to one another. Therefore, these mathematical concepts need to be studied and understood in accordance with their hierarchies. In learning mathematics, the teacher should provide material in a coherent and systematic manner so that there are no steps or stages of the concept that are passed. The aim is so that students can understand mathematics in full and deeper. For example, if a student wants to understand the concept of building a flat side space then he must first be able to understand the concept of flat wake. Likewise, if students want to understand the concept of flat building, they must first understand the concept of integer operations.

According to Wardhani (2008: 2) understanding the concept is the ability of students to explain the interrelationships between concepts and apply concepts flexibly, accurately, efficiently, and precisely in problem solving. From some of the opinions above, it can be concluded that understanding mathematical concepts is the ability of students to explain, associate, differentiate and apply each concept or idea that is new and which has been known precisely, accurately, effectively and efficiently. The indicators that show the ability to understand the concept are the ability to restate a concept, classify object objects according to certain characteristics (according to the concept), present concepts in various forms of mathematical representation, apply problem solving algorithms or algorithms (Wardhani, 2008: 2 and Jihad \& Harist, 2013: 149).

In addition to emphasizing aspects of concept understanding, mathematics also emphasizes thinking skills in solving problems both in mathematical contexts and in everyday life. One of the thinking skills that needs to be developed is critical thinking. As the opinion of 
Ennis (in Hassoubah 2008: 87) and Johnson (2009: 183) critical thinking is a profound ability to think in depth that requires someone to analyze various information actively, logically, and reasoned to be able to interpret and solve problems and determine decisions. The activity of critical thinking skills in question is the ability of students to determine the concepts used in problem solving, formulate an action (strategy, tactics, or approach) in solving problems, provide arguments or reasons in answering and solving problems, evaluating evidence or decisions that have been taken in resolve the problem (Ennis in Susanto 2013: 125)

Based on observations carried out in class VII of MTs-N Sampung Ponorogo, there were several problems regarding understanding concepts and critical thinking. Like, when the teacher asks to mention the concepts that have been learned, most of the students are unable to recite the concepts that have been studied before. Then, when the teacher asks students to give examples of concepts that have been learned, very few students are able to say the right answer. And when the teacher gives practice questions to do, most students copy the work of their friends who are smarter. When given a problem solving problem, most of the students have not been able to determine the concepts, strategies and tactics that will be used in solving the problem. When the teacher asks about the reasons for answering and solving problems, some students still experience confusion.

One aspect that can support the development of the ability to understand concepts and the ability to think critically is the use of problem-based learning models. Sani (2013: 149) states that problem-based learning is learning that is delivered by presenting a problem, presenting questions, providing opportunities for dialogue and facilitating students to conduct investigations related to solving a problem. In addition, the problem-based learning model has student-centered learning characteristics so that students in the learning process are more active in building their own knowledge.

In implementing a problem-based learning model, there are steps where students examine a problem and design a problem solving action plan. When reviewing, students classify the objects in the problem according to the nature of certain characteristics in accordance with the concept of the problem presented. So based on the results of the study, students are able to choose certain procedures or operations that are suitable to find solutions to problems. In this step, you can directly understand the concepts used.

Before students present and present a solution to a given problem, students first evaluate the evidence or decisions that have been taken in solving the problem. Thus, errors that might occur in procedures or algorithms in solving problems can be minimized or none at all. In this case students are indirectly given the opportunity to think critically and more deeply about the problem at hand.

Based on the problems described above, the problem-based learning model is assumed to have a good influence on the ability to understand concepts and the ability to think critically. So, the author intends to conduct experimental type research to prove whether the problembased learning model has a good influence on the ability to understand concepts and critical thinking

\section{RESEARCH METHOD}

The type of research used in this study is quasi-experimental or quasi-experimental. This is because researchers cannot provide full control of the external variables that influence it. Thus, the design form of this study is the non-equivalent pretest-posttest control group design. Schematically can be seen in figure 1 below. 


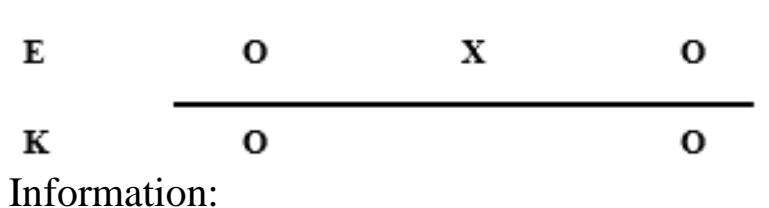

Information:

E: Experimental Class (using problem based learning models)

$\mathrm{K}$ : Control class (using conventional learning models)

$\mathrm{X}$ : Treatment

O: Pretest / Postest

This research was conducted at Sampung Ponorogo MTs-N in the even semester of the academic year 2017-2018. The population in this study were seventh grade students of MTs-N Sampung Ponorogo 2017-2018 school year consisting of class 5 classes namely VII A-VII E. The sampling technique used in this study was purposive sampling. The sample in this study were students of class VII A and class VII B. The technique of collecting data in this study used test techniques. The independent variables in this study were the learning models used. The dependent variable in this study is critical thinking skills and the ability to understand the mathematical concepts of class VII students in mathematics. In this study, the instrument used to collect data is in the form of description test questions which are arranged based on indicators of critical thinking skills and conceptual comprehension abilities. The initial data in this study were the pretest scores given before treatment was given. Furthermore, for the final data the posttest score is the ability to understand concepts and think critically after treatment is given

\section{RESULT AND DISCUSSION}

Hypothesis testing is used to find out whether the initial ability of critical thinking class is problem based learning model (PBM) and conventional learning class (PK) are the same. However, before that normality and homogeneity tests were carried out as a prerequisite for determining the hypothesis test used. In the normality test, the Shapiro Wilk test was used with the help of SPSS 18 software for Windows. The following table shows the results of the normality test for the pretest of students' critical thinking skills in the PBM class and the PK class.

Table 1. Results of Normality Test Calculation for Pretest Value Critical Thinking Ability PBM Class and PK class

\begin{tabular}{|c|c|c|c|}
\hline & \multicolumn{3}{|c|}{ Shapiro-Wilk } \\
\hline & Statistic & df & Sig. \\
\hline $\begin{array}{ll}\text { Skor BK Kelas } \\
\text { PBM }\end{array}$ & .940 & 23 & .183 \\
\hline Skor BK Kelas PK & .945 & 20 & .295 \\
\hline
\end{tabular}

Based on table 1, it is known that the significance value of the Shaphiro Wilk normality test for PBM class scores is 0.183 . While the significance value of Shaphiro Wilk class PK normality test is 0.295 . The significance value of the two classes is greater than $\alpha=0.05$ then H_0 is accepted which means the distribution of pretest score data critical thinking skills PBM class and PK class are normally distributed.

After the normality test, testing of variance was carried out using the homogeneity test. The following table presents the results of homogeneity of pretest scores in mathematics critical thinking skills of students in the PBM class and PK class using the Levene test with the help of SPSS 18 software for Windows.

Table 2. Results of Homogeneity Test Calculation Pretest Score Critical Thinking Ability 


\begin{tabular}{clll}
\hline $\begin{array}{c}\text { Levene } \\
\text { Statistic }\end{array}$ & df1 & df2 & Sig. \\
\hline .001 & 1 & 41 & .977 \\
\hline
\end{tabular}

Based on Table 2, the significance value of the levene test obtained critical thinking skills of 0.977 greater than $\alpha=0.05$ so that it was accepted. Then it can be concluded, the variance of the pretest score of critical thinking skills of PBM class students and homogeneous PK class students.

From the normality and homogeneity test, it is known that the pretest scores of students' mathematical critical thinking abilities are normally distributed and homogeneous, so that the average similarity test used is the Independent Sample T test. Independent Sample T Test results assisted by SPSS 18 for windows can be seen in Table 3.

Table 3. Results of Calculation of Average Equity Test Pretest Score Critical Thinking Ability PBM Class and PK Class

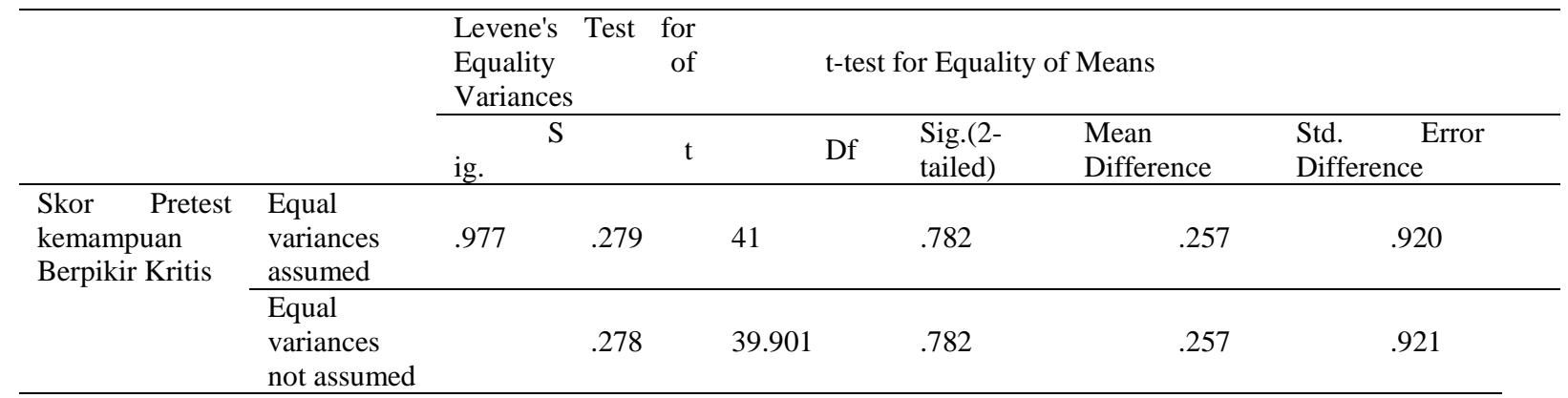

Based on Table 3, the independent value (2-tailed) of the Independent T Sample test the pretest score of critical thinking ability is 0.782 . The value (2-tailed) is greater than $\alpha=0.05$ then $\mathrm{H}_{-} 0$ is accepted. It can be concluded that the average initial reliability of mathematical critical thinking of students in PBM class is the same as the average initial ability to understand the mathematical concepts of conventional learning class students. The results of the analysis of the initial ability to understand the concept To find out the test used, the normality test is first carried out. Normality test is used to find out whether the pretest score of students' ability to understand mathematical concepts in PBM class and PK class is normally distributed. The following table presents the results of the normality test of the pretest score, the ability to understand the mathematical concepts of students in the PBM class and PK class, using the Shapiro Wilk test assisted by SPSS 18 software for Windows.

Table 4. Results of Calculation of Normality Test Pretest Score Concept Understanding Ability

\begin{tabular}{clll}
\hline & Shapiro-Wilk & & \\
\cline { 2 - 4 } & Statistic & df & Sig. \\
\hline Skor BK Kelas PBM & .963 & 23 & .534 \\
\hline Skor BK Kelas PK & .934 & 20 & .184 \\
\hline
\end{tabular}

Based on table 4, the significance value of the normality score for the PBM class is 0.534 . While the significance value of the normality test for the PK class pretest score is 0.184 . The significance value of the two classes is greater than $\alpha=0.05$, then $\mathrm{H}_{-} 0$ is accepted. So it can be concluded that the pretest score of the ability to understand the concept of PBM class and PK class is normally distributed. 
After knowing the pretest score of the ability to understand the concept of PBM class and PK class is normally distributed, the homogeneity test is conducted. The homogeneity test results can be seen in table 5 .

Table 5. Homogeneity Test Calculation Results Pretest Score Concept Understanding Ability

\begin{tabular}{clll}
\hline Levene Statistic & df1 & df2 & Sig. \\
\hline .001 & 1 & 41 & .098 \\
\hline
\end{tabular}

Based on table 5, the significance value of the levene test obtained by the concept understanding ability is 0.098 greater than $\alpha=0.05$ so that $\mathrm{H}_{-} 0$ is accepted. Then it can be concluded the variance of the pretest value of critical thinking skills in the PBM class and homogeneous PK class.

After it was discovered that the pretest score of students' ability to understand mathematical concepts was normally distributed and homogeneous, the similarity test on average used the Independent Sample T test. The results of the calculation of the similarity test on the average pretest score of PBM class and PK class using the Assisted Independent Sample $\mathrm{T}$ Test for SPSS 18 for windows can be seen in table 6 .

Table 6. Results of Calculation of Test for Similarity Average Pretest Score Concept Understanding Ability

Tabel 6. Hasil Perhitungan Uji Kesamaan Rata-rata Skor Pretest Kemampuan Pemahaman Konsep

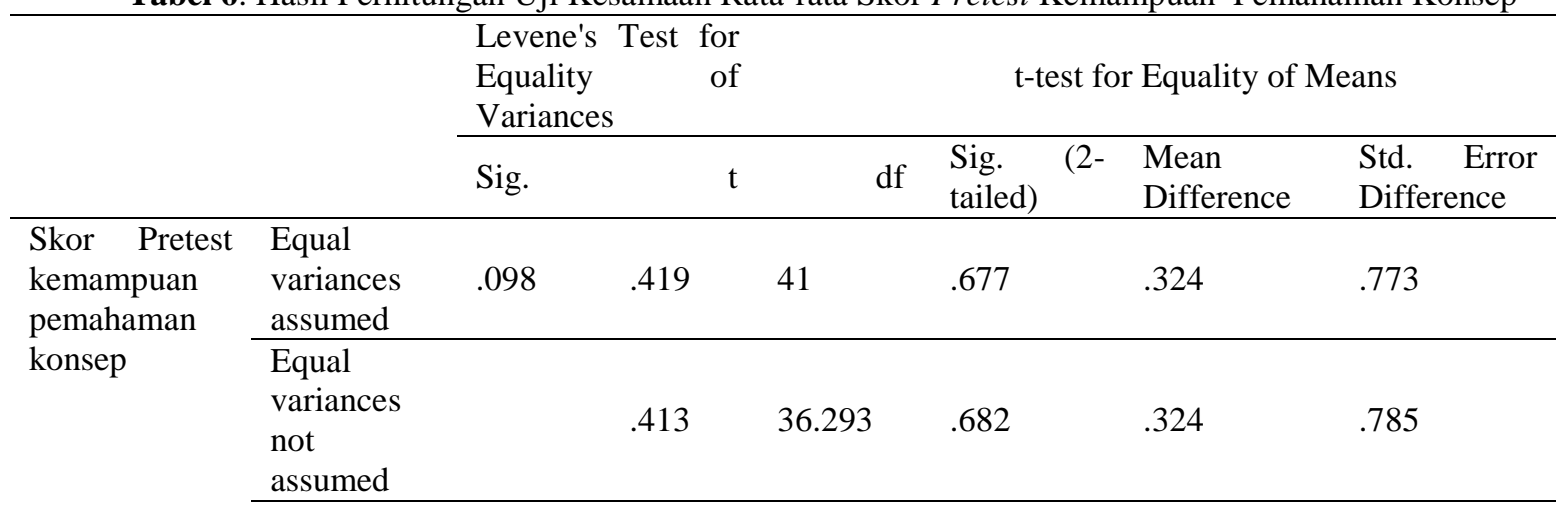

Table 6 shows that the large (2-tailed) Independent T Sample test pretest score concept comprehension ability is 0.667 greater than $\alpha=0.05$ then $\mathrm{H}_{-} 0$ is accepted. So, it can be concluded that the average initial reliability of understanding the mathematical concepts of PBM class students is the same as the average initial ability to understand the mathematical concepts of conventional learning class students.

The results of the analysis of students' final mathematical thinking abilities After the learning treatment is given, each student in the PBM class and conventional learning class is given the posture of mathematical critical thinking skills. The posttest scores obtained were tested to find out whether students 'critical thinking skills of mathematics based problem learning (PBM) were better than students' mathematical critical thinking skills in conventional learning classes (PK).

In terms of data distribution, the posttest score of critical thinking skills in PBM and PK classes is not nationally distributed. This is based on table 7 results of the normality test using SPSS 18 for Windows software which shows that the significance value of the normality test with Saphiro Wilk scores of students' critical thinking skills in PBM classes and PK classes are 0,000 and 0,001 , respectively. The significance values of the two classes are smaller than $\alpha=$ 
0.05 so that $\mathrm{H} \_0$ is rejected, which means that the posttest score of the critical thinking skills of the PBM class and PK class is not normally distributed.

Table 7. Results of Score Calculation of Normality Test Postest Critical Thinking Ability PBM Class and PK Class

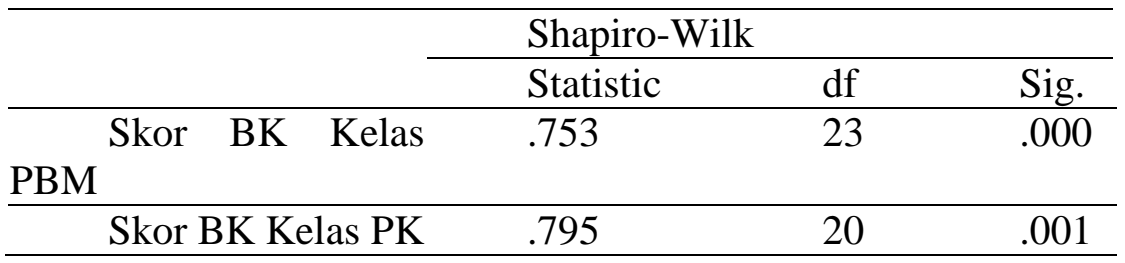

Based on the results of the normality test, the hypothesis test used is the non-parametric Mann-Withney U test. The aim of this test is to find out whether students 'critical thinking skills in problem-based learning (PBM) are better than students' conventional mathematical thinking skills. (PK). The Mann-Withney $U$ test results can be seen in table 8.

Table 8. Results of calculation of the Mann Withney Test U Postest Score Critical Thinking Ability

\begin{tabular}{ll}
\hline & Score of BK class PBM and \\
& PK \\
\hline Mann-Whitney U & 85.000 \\
Wilcoxon W & 295.000 \\
Z & -3.679 \\
Asymp. Sig. (2-tailed) & .000 \\
\hline
\end{tabular}

From table 8 the value $\left(\frac{\text { Asymp.Sig.(2-tailed })}{2}=\right.$ Asymp.Sig. $(1-$ tailed $)$ is equal to 0,000 . This value is smaller than the value of $\alpha=0.05$, which means that $\mathrm{H}_{-} 0$ is rejected. Therefore, it can be concluded that students 'mathematical critical thinking abilities using problem-based learning models are better than students' critical thinking skills using conventional learning. This is also supported by the results of the descriptive analysis of the average posttest score of students' critical thinking skills problem based learning class (PBM) and conventional learning class (PK). The average score of the two classes shows that the average posttest score of the problem-based ability of problem-based learning (PBM) is greater than the average posttest score of conventional learning class (PK) critical thinking skills with a ratio of 11.04>9.25

In addition, the problem-based learning model is a learning model which before starting the teaching and learning process in the classroom, students in groups are first asked to observe a phenomenon. Then students are asked to study and record the problems that arise. Thus students are encouraged to actively solve problems with group friends so that they can trigger students' curiosity when going to study a subject. At the same time, the teacher stimulates students' ability to think critically, systematically, and scientifically in solving existing problems with direction and guidance. According to Sanjaya (2014: 214) that the problembased learning model emphasizes the process of problem solving carried out using a scientific thinking approach. Where thinking scientifically can be interpreted by thinking logically, empirically and systematically. In addition, Permana \& Sumarmo (2007: 118) also say that problem-based learning encourages knowledge and understanding of concepts, achieves critical thinking, has learning independence, and skills in participating in group work, as well as the ability to solve problems. 
The results of the analysis of the final ability to understand the concept The final ability to understand students' mathematical concepts is obtained from the pretest score that is carried out after the treatment is given. The scores obtained were conducted using several stages of the test using the help of SPSS 18 for Windows Software to find out whether the ability to understand the mathematical concepts of PBM class students was better than conventional learning classes. First, the results of the Shapiro Wilk normality test on the ability to understand the concept of PBM and PK class classes indicate that the significance values of Shapiro Wilk's normality test are 0.12 and 0.20 , respectively. The significance value is smaller than the value $\alpha=0.05$ so that $\mathrm{H}_{-} 0$ is rejected. This means that the postest score of the final ability to understand the concept of PBM class and PK class is not normally distributed. The results of the normality test can be seen in table 9 .

Table 9. Results of the Calculation of the Normality Test Score Postest Understanding Ability of the Concepts of PBM Classes and PK Classes

\begin{tabular}{|c|c|c|c|}
\hline & \multicolumn{3}{|c|}{ Shapiro-Wilk } \\
\hline & Statistic & $\mathrm{df}$ & Sig. \\
\hline $\begin{array}{lll}\text { Skor BK Kelas } \\
\text { PBM }\end{array}$ & .883 & 23 & .012 \\
\hline Skor BK Kelas PK & .883 & 20 & .020 \\
\hline
\end{tabular}

Second, because the posttest score of the ability to understand the concept is not normally distributed, the hypothesis test used is the Mann-Withney U non-parametric test. The test results can be seen in table 10 .

Table 10. Results of Calculation of the Withney Mann Test U Postest Score Concept Understanding Ability

\begin{tabular}{lc}
\hline & Skor BK kelas PBM dan PK \\
\hline Mann-Whitney U & 85.000 \\
Wilcoxon W & 295.000 \\
Z & -4.283 \\
Asymp. Sig. (2-tailed) & .000 \\
\hline
\end{tabular}

Based on table 10, the value of Asymp is obtained. Sig. (1-tailed) $=0,000$ where the value is smaller than the value of $\alpha=0.05$. So, based on the hypothesis test criteria, H_0 is rejected and it can be concluded that the ability to understand the mathematical concepts of students who use the problembased learning model is better than the ability to understand the mathematical concepts of students who use conventional learning. This is also supported by the results of descriptive data analysis which shows that the posttest average score of the ability to understand PBM class concepts is greater than the posttest average ability to understand the concept of conventional learning class (PK) which is $12.43>10.05$.

In practice, problem-based learning encourages students to interact with each other to build their knowledge with their group friends by connecting some of the knowledge concepts they have mastered and then applying them to solve the problems at hand. From the interaction between students it can help students who are low and moderate in understanding mathematical concepts by sharing their knowledge with other friends. So that there arises the integration of mathematical concepts that can bring students to an understanding of certain mathematical conceptions. This is in accordance with his opinion Piaget (in Ruseffendi, 2006: 133) which states that knowledge built in the mind of a child is the result of active interaction with the environment through the process of absorbing new information into his mind (assimilation) and the process of rearranging his mind structure because there is new information received (accommodation). These findings are reinforced by Kono's findings (2016) that the problem- 
based learning model influences both the ability to understand concepts and the ability to think critically in biology subjects.

\section{CONCLUSION}

Problem-based learning models are better than conventional learning models in terms of students' understanding of mathematical concepts. Problem-based learning models are better than conventional learning models in terms of students' mathematical critical thinking abilities.

\section{REFERENCES}

Hasratuddin. (2014). Pembelajaran Matematika Sekarang dan yang akan Datang berbasis Karakter. Jurnal Didaktik Matematika, Vol. 1, No. 2, 30-42.

Hassoubah, Zaleha Ihzab. (2008). Mengasah Pikiran Kreatif Dan Kritis. Bandung: Nuasa.

Jihad, Asep \& Harist, Abdul. 2013. Evaluasi Pembelajaran. Yogyakarta: Multi Pressindo

Johnson, Elaine B. (2002). Contextual Teaching and Learning. Menjadikan Kegiatan Belajar Mengajar Mengasikkan dan Bermakna. Terjemahan oleh Ibnu Setiawan. 2009. Bandung: PT. MLC.

Kono, Rahmad, D.Mamu, Hartono \& N. Tangge, Lilies. (2016). Pengaruh Model Problem Based Learning (PBL) Terhadap Pemahaman Konsep Biologi dan Keterampilan Berpikir Kritis Siswa Tentang Ekosistem Dan Lingkungan Di Kelas X Sma Negeri 1 Sigi. Jurnal Sains dan Teknologi Tadulako, Vol 5, No. 1, 28-38.

Permana, Yanto \& Sumarmo, Utari. 2002. Membangun Kemampuan Penalaran dan Koneksi Matematik Siswa SMA Melalui Pembelajaran Berbasis Masalah. Jurnal Educationist, Vol. 1, No. 2, 116-123.

Ruseffendi. 2006. Pengantar Kepada Membantu Guru Mengembangkan Kompetensinya dalam Pengajaran Matematika Untuk Meningkatkan CBSA. Bandung: Tarsito.

Sani, Ridwan Abdulah. (2013). Inovasi Pembelajaran. Jakarta: Bumi Aksara.

Sanjaya, Wina. (2014). Strategi Pembelajaran Berorientasi Standar Proses Pendidikan. Jakarta: Kencana Prenada Media Group.

Susanto, Ahmad. (2013). Teori Belajar \& Pembelajaran di Sekolah Dasar. Jakarta: Prenada Media.

Wardhani, Sri. (2008). Analisis SI dan SKL Mata Pelajaran Matematika SMP/MTs Untuk Optimalisasi Tujuan Pembelajaran Matematika.Yogyakarta: Pusat Pengembangan Dan Pemberdayaan Pendidik dan Tenaga Kependidikan. 